DOI: 10.20472/IAC.2019.050.005

\author{
ALEXANDRA BOZHECHKOVA \\ The Russian Presidential Academy of National Economy and Public Administration, Russian Federation
}

\title{
REAL EXCHANGE RATE AND COMPETITIVENESS OF NATIONAL ECONOMY
}

\begin{abstract}
:
As a rule, the economic policy of various countries of the world, regardless of its specialization, is aimed at maintaining the competitiveness of the national economy. The nature of the relationship between the real exchange rate and competitiveness parameters essentially depends on the level of development of the economy, degree of development of the financial market, institutional environment, exchange rate regime, degree of dependence of the economy on the export of raw materials, accumulation of sovereign funds, etc. Thus, for developed countries, output dynamics are less affected by fluctuations in the real exchange rate, given the wide range of opportunities to diversify currency risks, as well as attracting external financing because of developed financial markets. In developing countries, underestimation of the exchange rate in the context of weak institutions, insufficient development of financial markets, and restrictions on borrowing can stimulate economic growth, increasing the profitability of producers of the traded sector of the economy.

It would be logical to assume that under the conditions of the inflation targeting regime, when economic agents while making decisions are less focused on expectations regarding the dynamics of the exchange rate and more take into account inflation expectations. Nonetheless, as the experience of developing countries targeting inflation shows, the monetary authorities continue to conduct currency interventions aimed at curbing the excessive strengthening of the national currency. Such measures, on the one hand, hinder the decline in the competitiveness of national goods on world markets, and on the other, they contribute to the expansion of investment opportunities of firms.

These theses are confirmed in our study. Econometric assessment of the degree of influence of the real exchange rate and its overvaluation / underestimation on economic growth rates, growth rates of total factor productivity (TFP), as well as the export diversification rate indicator was implemented by the system generalized method of moments for a group of CIS countries, countries of exporters of raw materials, developing countries that target inflation, on different subperiods: 1990s, 2000s, 2010s.
\end{abstract}

\section{Keywords:}

exchange rate, economic growth, total factor productivity, export diversification, system generalized method of moments

JEL Classification: C01, F00, E52 